parties. The morning after the decision of the House of Lords, he wrote to the Marquess of Tavistock, in a tone of mingled grief and anger, to condole with his Lordship on the temporary defeat of a measure which promised blessings to the country. The same morning was witness to an epistle on the same subject from the complaisant Knight to the Earl of Westmoreland. The conten's of the second letter were somewhat different from those of the first. Sir Henry had addressed Lord Tavistock as friend addresses friend on the occasion of some lanented bereavement; he spoke to Lord Westmoreland as friend spealss to friend at a marriage or a christening; " He was overjoyed, and, no doubt, his Lordship would be, at the final rejection of a bill which was pregnant with revolution, anarchy, and everything that was bad." The letters were folded and enclosed; but, alas! some one of those tiny mocking spirits that love to make game of good intentions, slipped Lord Westmoreland's note into Lord 'Tavistock's envelope, and Lord Tavistock's in to Lord Westmoreland's. The heir of the house of Russell read and pondered, pondered and read, and had just arrived at the charitable conclusion that poor Sir Henry was in a fair way to pay a visit to his brother Dr. Burrows, when, from certain family queries, he contrived to puzzle out the mistake, and his announcement of it reached Lord Westmoreland at the moment when the Earl was searching, but in vain, for a clue to the meaning of the lugubrious phrases in which Sir Henry lamented the success of a victory to which the noble Earl had so heartily contributed. Both the letters are in the possession of Lord Brougham. What Sir Henry said, or how Sir Henry looked, when the blunder was explained to him, we leave George Cruikshank to tell."

There, Sir, if that be fiction, then seld, $\mathrm{m}$ has fancy so successfully attired herself in the garb of truth; if, on the contrary, the statements be correct (and as yet I have seen no contradiction of them), then how admirably do they illustrate the fidelity with which yrur graphic LANCET has etched an "eel-backed courtier!" As to that part of the etching process denominated " biting$i h_{1}$, it may be remarked that you seldom fail in making it effective. The writer of the quoted paragraph asserts that "both the letters are in the possession of Lord Brousham" - that very nob'eman, respecting Sir Henry's double-conduct to whom, you made some cutting remarks soon after his accession to office. Lord B. must be puzzled to remember which of the Sir Henros is President of the College in Pall Mall East. Your obedient servant, T. J. H.

London, Dec. 27 th, 1831.

\section{TREATMENT OF CHOLERA}

ON A NEW PRINCIPLE.

By T. Sheldrake, Esq.

To the Editor of The Lascer.

Sir,-Under existing circumstances, you will, perhaps, excuse me for troubling you with this communication. Ten days ago, I Wrote a letter to Dr. JAmes JoH Nson, of which I subjoin a copy. In consequence, he called upon me, when I explained the treatment I alluded to, as well as it could be explained in the short conversation we had together; he seemed to think favourably of it, and advised me to write an explanation of it in THE Lancer, as the most effectual way to place it in the hands of those to whom it may be useful. In consequence of that advice, I trouble you with this application, to ask if you will insert this communication, and what space you can allow for it in your much-occupied pages.

\section{I am, your most obedient Servant,}

T. SHELDRAKE.

No. 73, Upper Berkley-st. Portman-sqDecember 11, 1831.

\section{To Dr. JAMES JoHNSON.}

Sir,_-You will, perhaps, excuse this communication from a stranger, when his motive for making it is explained. I have no knowledge of cholera morbus, other than may be obtained by a cursory perusal of the writings in circulation. Practically, I know nothing about it. I have just read in $\mathbf{T H}_{\mathbf{R}}$ LA NCET, the "propositions" which you laid before the Westminster Medical So. ciety, on Saturday, November 26, and was very forcibly struck with the following passage.

"No. 18. The external remedies are three-heat, friction, and counter-irritation. These three means sbould be employed, not only simultaneously with re. spect to each other, but contemporaneous $y$ with the internal remedies. They should also be so employed that the patient may not be required to throw a single voluntary muscle into action. Every muscular movement, even that of sitting up in bed, is prejudicial, or absolutely dangerous."

It would seem, that in the above passage, you were describing a practice in which I have been extensively and successfully employed more than forty vears, without making the particulars known to the profession, but which I will develope to you so far as it may be applicable to the treatment of cholera, according to your view of that important disease.

My object, in my own practice, was to produce alteration in the organic structure of some muscles, in the persons of those 
upon whom I was occupied. In this I have : partment which is my peculiar province, and always succeeded; and in doing it $I$ have has been so beneficial to those for whose beinvariably found that $I$ effected an increase! nefit it was adopted, that I have long deter. of circulation in the $\operatorname{limb}$ upon which I mined to publish what I have seen on the operated, and was surprised to find that, at subject; but as my engagements oblige me no distant interval, the beneficial results, to postpone that work to an indefinite period, as to improvement of general health, ex and I see that the passage 1 have quoted tended to the whole person of my patient. from your papers bears directly upon the I could not witness this, undeviatingly, and subject, I thought you would excuse my in daily progress, without endeavouring to offering it to your notice, and asking whe. ascertain the cause of so remarkable an ther you think with me that it might be in effect, and I succeeded in convincing myself any way beneficial on the present momentthat it was owing to two circumstances.

ous occasion.

First, when the heart, no matter from what canse, could not impel the blood into the arteries with sufficient force to keep up a bealthy circulation, I, by artificial action upon the extremities, without the least exertion of the patient, impelled the blood towards the heart, and thus a healthy circulation was restored and kept up for any time that was required, without the patiest making any exertion to obtain it.

The second was to produce increased ac. tion upon the surface of the body, without excessive irritation, or at least with such a degree of counter-irritation as would be beneficial without producing inconvenience to the patient, the active material being conveyed into the system by the absorbents, without passing by the stomach. To accomplish this I use the etherial spirit of turpentine, not as an embrocation, but as an external application, so managed as to be in close contact with the body for many days together, without producing any unpleasant irritation, at the same time that a constant, genial, and extensive glow is kept up in the whole limb to which the application is made. This is effected by the management which prevents the spirit evaporating from the surface, where it remains till it is $a b$. sorbed and carried into the system, thus producing the effect that is expected from it.

I am borne out by your statement, in be. lieving this practice would prove beneficial in the treatment of cholera. In several statements which I have seen, spirit of turpentine is said to have proved beneficial when administered by the stomacb, though its effects upon that organ must be disagreeable to the patient, before its beneficial efrects can be felt; but by introducing it into the system in the manner I have described, and keeping it there to any extent that may be desirable, the stomach is left open to the operaiion of any other class of medicines it may be thought expedient to em. ploy.

The fact,--that the circulation may be maintained, by extraneous means, to any ex. tent, and the patient, during the whole time of the process, remain quiescent, - has long been known to me, and practised in many cases, besides those belonging to that de.

I am, Sir, your most obedient servant, T. Sheldrake,

\section{3, Upper Berkley Street,} Portman Square.

Davis's Midwifery.-Part II. of Dr D. Davis's "Principles and Practice of Obstetric Medicine," was publis hed on the 1st of December and fally supports the bigh character which has been so universally bestowed on the first part. We shall notice the work at some length on another occasion, but in the mean time we earnestly recom. mend it to the attention of practitioners and students. Part III. is to appear January 1st, 1832.

\section{CORRESPONDENTS, \&c.}

Comannicatrons have been received from Philanthropos-Mr. J. R Young-A Non. medical Subsciber-Mir J. Baker-Tyio-A Con. stant Reader (Bristol)-Mr. Willeacl- Mi. J. H. Tucker.

$A$. $\dot{B}$. inquires if there are "any "recng. nised "medical lecturers at Cork." We regret that we cnurot answer the question; probably a correspondent will farour $A$. B. by communicating the information whin he desires.

An Apprentice, and Junior Subscriber. In courtesy the conrt ull admit our corre an examination under the circumstances which he describes, but he could not, at lav, enforce a com. pliance with his demand. In order, however. to prevent disappointment, he should apply to the court non, state his ease, and inquile in distint terms, whether they will admit him to exaninatuon if he devote the last eight months of his time, specified under the indentuies, to an attendance on lec. tures in London.

Mr. J. R. Young. The inhalation of oxt. gen gas has been tred alone, and in conjunction with many other rermedies, but in no instance with a successful result.

MLr. J.P. (Coventry). The proposals contain nothing new. The remedies have all ben tried and have failed.

Mr. Her 'y M-tt, writing, we suspect, in rather a waggish mood, makes the followng suggestion:- "Let erery pari-h be compalled to tlu. nish fion its puorhouse a certain monbry of dret bodies annually to the neanest licensel sutwol of anatorny, according toits anonit of population, and the deniand of the schools." 